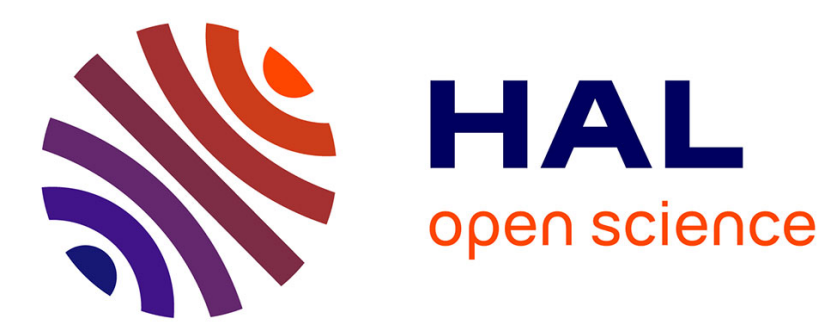

\title{
Introduction to the GM and non-GM supply chain co-existence and traceability
}

Yves Bertheau, John Davison

\section{To cite this version:}

Yves Bertheau, John Davison. Introduction to the GM and non-GM supply chain co-existence and traceability. Genetically modified and non-genetically modified food supply chains: co-existence and traceability, Wiley-Blackwell, 2013, 9781444337785. 10.1002/9781118373781.ch1 . hal-02806081

\section{HAL Id: hal-02806081 https://hal.inrae.fr/hal-02806081}

Submitted on 6 Jun 2020

HAL is a multi-disciplinary open access archive for the deposit and dissemination of scientific research documents, whether they are published or not. The documents may come from teaching and research institutions in France or abroad, or from public or private research centers.
L'archive ouverte pluridisciplinaire HAL, est destinée au dépôt et à la diffusion de documents scientifiques de niveau recherche, publiés ou non, émanant des établissements d'enseignement et de recherche français ou étrangers, des laboratoires publics ou privés. 


\title{
1
}

\section{Introduction to the GM and Non-GM Supply Chain Co-Existence and Traceability}

\author{
Y. Bertheau, J. Davison
}

\subsection{INTRODUCTION}

The arrival of GM soybeans in the European Union in 1996 was a very controversial issue with respect to both their importation and their possible cultivation. In response to this rising controversy, the European Commission and the European Member States initiated, in several steps, a strong legal framework to take into account the consumers', producers' and industries' fears and viewpoints and launched several research programmes to provide appropriate technical solutions.

This book is mostly a follow up of the European research project 'Co-Extra' which ran from 2005 to 2009. Co-Extra was the largest EC 'integrated project', on co-existence and traceability in food and feed supply chains, and had a budget of $24 \mathrm{M} €$ and more than 200 scientists and their teams from 18 countries, including Russia, Argentina and Brazil.

Despite the large budget and scope of work of Co-Extra, of course not all aspects of co-existence and traceability in supply chains could be fully covered. Risk assessment and post-market monitoring were also not part of the aims of Co-Extra. Several complementary pieces of information were thus requested for this book from authors involved in similar European or national research programmes. We also integrated a synthetic contribution from several Asian colleagues working in other parts of the domain of coexistence and traceability. All these colleagues are gratefully acknowledged for their useful contributions.
A synthesis based on a compilation by the European Commission of the Publishable Final Activity Reports (PFAR) of several European projects was recently issued (European Commission, 2010b) showing the results from the more than $200 \mathrm{M} €$ of investment of the European Union spent looking for answers to citizens' questions. The research projects covered approached risk evaluation, co-existence and traceability, but not post-market surveillance which began to be considered by the EC during the last call for proposals of the FP7 (January 2011). This PFAR synthesis may help readers to find complementary information to the issues raised in this book.

So far this present book is the largest and most up-todate compilation on GM and non-GM supply chain coexistence and traceability.

The tools, methodologies, strategies and guidelines developed for GMO are currently used in several other traceability sectors. Conversely, the other fields of traceability also fertilised the GMO field as can be seen in a recently published book (Hoorfar et al., 2011).

\subsection{GMO DEVELOPMENT}

In 1983, three reports from the University of Ghent, the University of Washington and the Monsanto Company showed that the Ti plasmid of Agrobacterium tumefaciens could be used to transfer foreign DNA into a plant genome, thus producing the first genetically modified (GM) plants. 
This discovery had enormous implications for plant genetics and agriculture. In the last 20 years, plant biotechnology has grown into a multibillion-dollar international industry, mostly focused on commodities but also encompassing some niche markets such as the GM virus-resistant papayas which saved the Hawaiian crop (Davison and Bertheau, 2008; James, 2011).

While the global cultivation area of GMOs reached approximately 150 million hectares in 2010 , the total area cropped with GM crops in the European Union (EU) was approximately 110 thousand hectares (James, 2011). The earliest and still most important commercialised transgenic plants are maize, cotton, soybean and canola, and they contain transgenes conferring tolerance to herbicides, or resistance to insects and pests.

The cultivation of GM crops is presently limited to a few countries. The United States grows 55\% of GM crops, followed by Argentina (19\%), Brazil (10\%), Canada (7\%) and China (4\%). Europe cultivates almost no GM crops, except for a relatively small amount of maize in Spain and Portugal and some European Union Member States (EU-MS). The adoption rate of GM crops thus shows considerable disparities between different agricultural production regions worldwide and within the EU.

Most approved GM crops worldwide are thus currently cultivated outside the EU, but might subsequently be imported and eventually further processed in the EU mostly for feeding purposes (Bertheau and Davison, 2011). Today, Bt-maize expressing the insecticidal protein Cry1A(b) from Bacillus thuringiensis, for fighting European and Mediterranean corn borers, is the GM crop most cultivated in the EU. This resistance remains effective, though a recent report showed the appearance of corn rootworm resistant to Bt maize only after three years of cropping, which shows that good cropping practices must always be used (Gassmann et al., 2011; Shike, 2011). A recent cultivation approval of a GM potato for industrial uses (13 years after the initial application by a company now owned by BASF) may initiate a long series of cultivation approvals in the EU since numerous requests for such authorisations are in the European pipeline, including the GTS-40-3-2 soybean.

In the next few years, this situation is likely to change dramatically. China is expected to dramatically increase its transgenic crop cultivation, currently mostly focused on cotton. However, despite recent rice approvals, GM rice is not officially cropped in China (Chen et al., 2011). Chinese GM cotton cultivation, which affected other crops - mostly orchards - over long distances, shows the need for accu- increases in GMO cultivation are foreseen in India, South Africa, Australia and even Europe where several dossiers for GM cultivation are in the pipeline. Emerging countries such as China show increasing life standards and thus an augmentation of meat consumption and protein imports. These imports participate in the development of international trade and increases in agricultural commodities' prices (Bertheau and Davison, 2011). However, until now, GMO producers have not released GMOs with improved organoleptic or nutritional improvements, nor industrial products such as pharmaceuticals which appear to be more acceptable to consumers.

In parallel, several new genetic modification tools, epigenetic based tools and synthetic biology have appeared over the last few years which allow cleaner transformation of plants with, for instance, directed mutagenesis of specific loci, or provide a completely new organism (Cohan, 2010; Frizzi and Huang, 2010; Glick et al., 2010; Lusser et al., 2011; Mirouze and Paszkowski, 2011). The status of these new modified organisms (i.e. whether they should be considered as genetically modified or not) is still under discussion in the European Union, where an expert committee is currently discussing this with the European Commission's representatives. It is highly probable that recommendations will differ between the world's regions (Jacobsen and Schouten, 2009; Schouten et al., 2006). However, it is to be expected that such newly modified organisms will not arrive rapidly on the market since several intellectual properties rights and regulations may compete and, more particularly, current GMO producers will attempt to continue to profit from currently approved GMO, for instance through stacked genes. Moreover, the elapsed time between an innovation and its commercial application may need to be a decade when considering the classical breeding necessary for providing locally adapted cultivars.

Finally, as some of these new techniques will benefit from the current germplasm collections of crops and high throughput sequencing, they will also in several instances need the introduction of sequences of foreign organisms, thus falling within the current scope of GMOs. The regulatory framework of the more favourable countries such as the USA may also have to evolve, as currently pointed to by the GM Kentucky bluegrass issue (Editorial, 2011; Ledford, 2011).

\subsection{OPINIONS AND ATTITUDES OF EUROPEAN CITIZENS AND CONSUMERS}

Since the arrival in 1996 of the first shipments of GM soybean in European harbours, European citizens and consumers have had rather sceptical opinions and attitudes 
over GMOs. A strong opposition movement to GMOs developed in many countries, especially in Europe, with concomitant destruction of field trials, although these technologies were presented from the outset as highly promising and their advantages were frequently highlighted (Brookes and Barfoot, 2011a, b). Fostered by several highly publicised and successive food safety crises, none of which concerned GMOs, European public suspicion towards regulatory authorities, scientists' expertise and technocratic decision-making grew due to lack of public participation (Davison, 2010; Davison and Bertheau, 2008; Löfstedt, 2004; Richard, 2011; Winickoff et al., 2005). This controversy had several impacts on international trade with, for instance, shipments being refused entrance to the EU, which worried the farmers of exporting countries and their national authorities as well as international traders. Curiously, the European directive on botanical impurities in feed, that is the acceptance of some traces of a product not used in the compound feed, does not apply when GMO are concerned, despite current discussions on the issue (European Commission, 2004d; European Commission. DG SANCO, 2011).

However, this public reluctance about GMOs is representative of a general request over the two last decades for more societal debate, deliberative democracy together with questioning of expert legitimacy and evaluation bodies (de Jonge et al., 2007; Devos et al., 2008; Felt and Fochler, 2008; Ferretti and Pavone, 2009; Frewer. et al., 2004; Granjou and Valceschini, 2004; Hogg et al., 2008; Levidow, 2007; Lien and Anthony, 2007; Meghani, 2009; Moore, 2010; Winickoff et al., 2005). Moreover, several farming and industrial issues in the USA and China further decreased the trust of citizens in the ability of the seeds industry and farmers to control GMOs, as can be exemplified by the unexpected release into the environment of for example US LL601 rice or Bt10 maize or of Chinese Bt63, Kefeng6 and KMD1 rice (Bratspies, 2003; Cowan, 2011; European Commission, 2005, 2008b; Fox, 2003, 2011; Li et al., 2010; Miller, 2010; Vermij, 2006).

This trend, towards more societal debate and distrust of industries and experts, grew alongside a more general request for more sustainable, local and traditional food with some direct interaction with a producer. This recent trend is in the opposite direction to that of the 1990s for delocalisation and in general and more particularly for food production, finally transforming into requests for an 'economy of quality' (Almli et al., 2011; Brown et al., 2009; Chambers et al., 2007; Chiffoleau, 2009; DeLind, 2011; Guerrero et al., 2009; Nie and Zepeda, 2011; Pieniak et al., 2009). Such socio-economic issues were raised during the 2008 meeting of the European council of ministers of environment who asked for reform of the EFSA approval criteria and consideration of socio-economic issues by the EC in the GMO approval process. So far, only the French and Dutch European evaluation bodies have integrated socio-economic and ethical issues into their recommendations or advice (European Commission, 2011; Pauwels et al., 2010).

However, European opinion over biotechnologies might be changing, as observed by the different Eurobarometer polls and their variations over the last years according to price variations (Bonny, 2003, 2008; Brook Lyndhurst Ltd., 2009; Bütschi et al., 2009; de Cheveigné, 2004; European Commission, 2008a; Gaskell et al., 2006; Gaskell et al., 2010; Marris et al., 2001; TNS Opinion \& Social, 2010). Moreover, opinions and attitudes may also differ as the public may be under-informed and thus unaware of GMO issues or may simply not read the labels (Brook Lyndhurst Ltd., 2009; Esposito and Kolodinsky, 2007; James, 2004; Noussair et al., 2001a, b, 2004; Sheldon et al., 2009). Indeed, a study pointed out that when given freedom of choice (between GM and non-GM products) consumers may simply choose the less expensive option (Consumerchoice Consortium, 2008). However, this attitude does not seem uniform among the European countries. But, this study also suffers from extrapolating excessive conclusions from the results. In particular the willingness of consumers to move toward GMOs, mostly observed in the middle Europe, cannot be generalised to the western part of the EU.

This generally stigmatised European reluctance toward plant biotechnologies is in fact shared widely among countries and cannot be easily linked to knowledge and education level, but is most probably affected by the source of information, or the lack of information through missing labelling (Hoban, 2004; House et al., 2003; Lockie et al., 2005; Rollin et al., 2011; The Melman Group, 2006). Among the important factors for rejection, we can outline the focus on the potential risks of GMOs and the extensive publicity given to these, coupled with the inadequacy of answers to these diverse criticisms, and thus a drawing up of an unfavourable risk-benefit balance, despite several favourable peer-reviewed papers and reports to the European Commission (Bartsch et al., 2009; Bonny, 2003; Henry et al., 2006; Kaphengst et al., 2011; Noussair et al., 2002). GMO exporting countries have also emphasised the great importance of retailers or industrial companies that are, according to their opinion, against GMOs. However, several important CEOs of global companies have in fact clearly expressed their favour towards GMOs, but wish to 
be seen to be following their consumers' wishes (Anonymous, 2008; BBC Radio4, 2010; PA, 2010; Schneider, 2007).

As is common in a democracy, but without a clear registration of lobbies in the EU, intense lobbying campaigns were launched by both pro- and anti-GMO stakeholders and scientists through direct advertisements, NGOs such as Greenpeace and Friends of the Earth, or the use of lobbyists such as ISAAA or PG Economics or other favourable industrial associations such as ILSI (Kleinman and Kloppenburg, 1991; Miller and Conko, 2004; Prat, 2011; Reynolds, 2004).

Consumers' preferences as well as the national importance of traditional or organic farming or quality signs may largely explain the differences in behaviour between EU Member States (Kurzer and Cooper, 2007a; Kurzer and Cooper, 2007b). This European trend is also observable in several third countries, including the USA, some of them establishing a mandatory labelling of GMO and derived products which has not proved possible in others, such as in the USA where the 14 states that attempted to impose labelling were impeded by federal government rules (Hwang et al., 2005; Rousu et al., 2004). In fact, similarly to other disputes between states, such as carbon footprinting, or more generally speaking environmentally linked issues and geographically based signs-of-quality, the capacity given to consumers to keep their freedom of choice through appropriate labelling looks to be a determinant factor of consumers' behaviour; an issue generally raised at the WTO level as a foundation of food sovereignty (Bütschi et al., 2009; Hilson, 2005; Marette et al., 2007; Marette et al., 2009; Roberts et al., 2001; Strauss and Strauss, 2009; The Melman Group, 2006).

To conclude, the states, within and outside the EU, are oscillating between several forces originating from their history, citizen trends and international treaties. However, several countries favour their industries' viewpoints and are generally less likely members of constraining treaties that could impact their employment and industries lobbies, as can observed, for instance, for the Cartagena Biosafety Protocol. Moreover, the revolving door system between administrations and companies, as observed in the EU and third countries, accentuates the sensitivity of states to industries' interests (Hladky, 2011; Meghani and Kuzma, 2010; Newell, 2003).

\subsection{THE DIFFERENT REGULATORY FRAMES AND RISK PERCEPTION}

In democratic countries, the risk perception of citizens is a major driver of regulatory frameworks. It is therefore necessary to appreciate risk perception viewpoints in order to understand the nature and aim of legislation on traceability and co-existence in supply chains. This trend may be briefly exemplified by the European fears about food safety due to the BSE scare or US fears on food security after the 11 September events, as well as consumers' lack of trust in their governmental bodies (Finucane, 2002; GAO (US General Accouting Office), 2011; Lisbet, 2004; Oosterveer, 2007).

\subsubsection{Risk perception}

As outlined by several authors the risk perception for GMOs, as well as risk-benefit analyses and associated risk communication, may differ between countries (Durant and Legge, 2005, 2006; Finucane and Holup, 2005; Frewer et al., 2011; Frewer et al., 2003a; Frewer et al., 2003b; Guehlstorf, 2008; Guehlstorf and Hallstrom, 2005; van Dijk et al., 2011). This kind of distortion is not new and has been observed throughout history, for instance between countries and people in the 1950s and 1960s during the introduction of maize hybrids, or currently in the mobile phone phenomena where there are fears about either antennae or mobiles, depending on the side of Atlantic you are on.

As outlined by several scholars (see for instance Bonneuil and Thomas (2009), this reluctance of citizens and some growers in the face of new cropping technologies is mostly part of personal cost-benefit analyses by the farmers of the putative social effects of the adoption of these new agricultural technologies, a trend generally abusively qualified as the neo-luddite movement (Kleinman and Kinchy, 2007; Noble, 1983).

The technical, as well as societal, risk evaluation differs among stakeholders who may invoke ethical issues (Levidow and Carr, 1997). Despite several claims of pro-GMO campaigners, the citizens and consumers of countries with the largest GMO hectarages are generally unaware of GMOs, believe that they do not eat them and more generally request to know if they do, by appropriate labelling, as shown by several studies including the PEW initiative on food and biotechnology (Prakash and Kollman, 2003; The Melman Group, 2006). The citizens and consumers' fears are thus rather similar between cropping GMO third countries and those, as in the EU, with labelling established for consumers that keeps their 'right to choose' (Bonny, 2003; Gaskell et al., 2006; Gaskell et al., 2003; Prakash and Kollman, 2003; TNS Opinion \& Social, 2010). As outlined by Prakash and Kollman (2003), a regulatory convergence between USA and EU may be initiated. This hypothesis of convergence of some US 
regulation towards a more European regulatory style is supported by other authors, and is reinforced by other considerations such as traceability and the recent announcement by the USDA that the agency can no longer study further new GMOs due to its mandate (Davison, 2010; Editorial, 2011; Ledford, 2011). Indeed, escaped GMOs, such as LL601 rice or Bt10 maize and the Chinese rice found in the USA, all militate for a better traceability of GMOs as requested by the US General Accounting Office, while the recent disputes about alfalfa and sugar beet approvals support the need for co-existence rules between organic, conventional and GMO cultivations as stated by US Secretary, Wilsack.

These different risk perceptions may be reflected in different evaluation systems. These views also influence perceptions of socio-economic issues and policies such evaluation agencies' independence, the acceptability of the revolving door system between companies and administration, the public's and farmers' request to participate in an evaluation system, the sustainability approaches including socio-economic issues such as the effect on farms' structures, and finally the sustaining concepts such as 'substantial equivalence', which may, or may not, be used in these countries (Ervin et al., 2011; Levidow, 2007; Levidow et al., 2007; Taylor, 2007). Despite being relatively scarce in the EU, the revolving door system looks to expand, thus mimicking the US 'model'. Farming structure is also of utmost importance when considering agriculture's sustainability and its different meanings and definitions. For instance around $10 \%$ of US farms deliver $75 \%$ of commodities, while 2 million smaller farmers deliver the remaining $25 \%$, a figure widely different from the European one which may, in several ways, explain the differences observed between agricultural production schemes and sustainability as well as the surrounding legislations and subsidies (Hoppe and Banker, 2010; Hoppe et al., 2007).

\subsubsection{Regulatory and responsibility frames}

Since 1990, GMOs have been subject to a series of European directives and regulations for risk assessment for confined uses or for dissemination into the environment (1990/220/EC, 1990/219/EC, 1139/1998/CE, 49/2000/CE, $50 / 2000 / \mathrm{CE}$ some of them replaced by 1998/81/EEC, 2001/18/EEC and 1829/2003/EEC). In the late 1990s, the growing societal and political opposition contributed to a de facto moratorium on new market approvals of GM crops. This was adopted at a meeting of the EU Council of environmental ministers in June 1999, where five Member States decided not to accept new GM crop market approvals until the existing regulatory frame was revised (Winickoff et al., 2005). Several agro-food biotechnology market applications remain blocked in the approval pipeline in the EU.

From 1999 onwards, policy-makers began to revise the legal conditions under which GM crops and agro-food products were allowed to be used in the EU, to slow down further erosion of public and market confidence (Devos et al., 2006).

Post-market environmental monitoring and traceability were legally adopted as ways to cope with scientific uncertainties as part of the precautionary principle. Most of the guidelines comply with supra-national bodies such as OECD and Codex Alimentarius which, in the latter case, establishes standards to be used by the WTO. However, this reform of European regulation was unable to provide notifying companies with the simple one door - one key tool targeted by the EC. Currently, dossiers are notified either under the 2001/18 Directive or under 1829/2003 Regulation, which is a source of confusion as exemplified by a recent judgment of the European Court of Justice in the case of the French moratorium of Mon810 cultivation, a moratorium resulting from the 'Grenelle de l'environnement' negotiation after huge contests resulting from the use of the European safeguard clause by France (Bloom, 2011; Dunmore and Toyer, 2011; Marris et al., 2004; Stapleton, 2011). After two decades with national evaluation agencies and a rather complex evaluation system, the European Union decided, after several health issues such as BSE, to create the European Food Safety Authority (EFSA; Davison and Bertheau 2007, 2008; European Commission, 2002). EFSA released several scientific opinions on risk assessment methods, statistics and post-market monitoring beside its own opinions on individual dossiers. Several European stakeholders have pointed out, however, that up to now EFSA has only delivered positive opinions about all submitted dossiers, while several EU Member States have pointed out that the opinions and questions of national advisory bodies should be better taken into account. Similar complaints have also been addressed to foreign agencies, and more particularly the USA, which are, at least for USDA, generally considered as business-friendly (Prakash and Kollman, 2003). A reform of EFSA procedures was also requested by EU member States during the 2008 meeting of the Council of Environment Ministries.

Due to several past disagreements between the former European Commissioner S. Dimas in charge of environment (and of the GMOs dossier), and President Barroso of the European Commission, the GMO dossier is currently 
under the unique charge of the Commissioner of Health and Consumers' Protection (DG-SANCO). This concentration into the hands of a single European DG, considered by several European NGOs as relatively favourable to GMO approvals and in direct interaction with EFSA, has been seen by numerous European actors as a statement on the second Barroso's Commission favouring of development of GMOs in the EU.

This view may be supported by several declarations of the new Commissioner in charge of DG-SANCO and by the deal proposed by President Barroso to EU Member States to facilitate and speed up GMO approval in exchange for possible national bans of these EU approved GMOs, provided the Member States do not refer to the health and environment issues already examined by EFSA (AFP, 2011; Kanter, 2010).

All these socio-economic and ethical considerations and the corresponding lobbying actions resulted in a strong European regulatory framework on the follow up of commercial approvals of GMOs. Co-existence and traceability are two examples of this result, while a third, post-market monitoring, is outside the scope of this book.

\subsection{EUROPEAN TRACEABILITY AND CO-EXISTENCE FRAMES}

\subsubsection{The traceability frame}

As a response to consumer demand for keeping their right to choose, detection, traceability and labelling are mandatory in the EU (regulations 1829/2003 and 1830/2003/EC, Directive 2001/18). This vertical European regulatory frame is in fact based on specific regulations such as the $258 / 1997 / \mathrm{EC}$, on 'novel food and novel ingredients', or general ones such as the 178/2002/EEC (" General Food Law') regulation on food traceability. A labelling threshold was established at $1 \%$ per ingredient, then $0.9 \%$, according to several technical feasibility studies and economic and agricultural production scenarios, among which was a 1998 French study on the effect of several thresholds (from 0.01 to $5 \%$ ) on agricultural production organisation (European Commission, 2000, 2003b, 2007). Reports on traceability implementation were provided by the EC to the European Parliament (European Commission, 2008c). To support research, favour exchanges between EU Member States and enforce this set of regulations, the European network of GMO laboratories (ENGL) was officially set up in 2002 and is chaired by the JRC-IHCP. ENGL was created following the 1998 French and Belgian initiatives to constitute national networks between re-
German network of enforcement laboratories. This European network of both enforcement agencies and research laboratories mandated by EU Member States established several guidelines on, for example, performance criteria of ring trial validation of methods provided by notifying companies.

As the unit to be used for calculating the GMO content per ingredient was not provided in the regulation, the EC released a recommendation establishing the 'haploid genome equivalent, (HGE)', (i.e. the monoploid DNA content), as the unit to be used despite strong lobbying from stakeholders and some EU Member States for alternative calculation units such as kernels (European Commission, 2004a). This decision, based on a recommendation of the ENGL, was mostly motivated by the practicability of this unit, usable from seed to processed compound due to DNA resistance to industrial transformation and its several specificity levels (from screening to GMO identification), despite the French request to keep all kinds of measurement units. While this unit initially favoured the companies with heterozygous plants, such as hybrid maize, by decreasing the HGE-based GMO content, its use in stacked GMOs is currently being reconsidered due to international trade considerations, that is a rapid increase of GMO content without corresponding mass increase (Holst-Jensen and Berdal, 2004).

After the signing of the Cartagena Protocol, the EU released a regulation on trans-boundary movements of living GMOs (European Commission, 2003c; Grossman, 2005). According to this regulation, the quality of products to be exported should be similar to that for domestic markets.

A second network of national references laboratories (NRL) was then set up by Regulation 882/2004 for working with the European Reference Laboratory for GM Food and Feed (CRL-GMFF then EURL-GMFF). Most members of this network, also chaired by the JRC-IHCP, are members of the ENGL. A European reference laboratory (the EURLGMFF, formerly CRL-GMFF) was established at the European Joint Research Center of Ispra (Italy) for validating the detection methods to be submitted by the petitioning companies, which incur flat-rate fees for validation made by the ENGL laboratories (European Commission, 2004b, d; European Commission. DG SANCO, 2011; Food Chain Evaluation Consortium, 2009). All validated detection methods are made publicly available which not only helps enforcement laboratories, but also private ones, in the harmonisation and standardisation of methods. Finally a quality assurance system was put in place with an accreditation scheme (Zel et al., 2006; Zel et al., 2008). 
ENGL also released several documents such as performance criteria to be met by detection methods submitted by the companies or on guidelines on the detection of unapproved GMOs.

In parallel to the development of GMO detection methods, an important standardisation work was launched in 1999 at the national, European (Comité Européen de Normalisation; CEN), and then international (International Standard Organization; ISO) levels. Several standards are currently available, in particular a CEN/ISO standard on the general guidelines and performance criteria of GMO detection methods. This international standard was largely inspired by the 2000 French standard. Sampling is the only aspect that was not standardised at the ISO level but remains a technical document. Generally speaking, sampling remains an important issue, as exemplified by the EC recommendation on the sampling of shipments which is not routinely used by EU Member States for GMO detection due to its impracticability and high costs, despite its accuracy (Davison and Bertheau, 2007, 2008; Davison and Bertheau, 2010; European Commission, 2004a; Kay and Paoletti, 2001; Paoletti et al., 2003; Paoletti et al., 2006). For the first time, the polymerase chain reaction (PCR) was applied to whole supply chains, and their very different products, in a systematic and, as far as possible, standardised manner. Disputes, and more generally speaking liability and redress issues, are still being discussed as to who should support the traceability costs, since the non-GMO producers are requesting that newcomers, that is the GMO producers, should bear the incurred costs.

\subsubsection{Co-Existence issues}

While these directives and regulations attempt to provide freedom of choice to European consumers through accurate labelling and traceability, the freedom of producers to keep their choice of production was set up through a 2003 EC co-existence recommendation that has been recently updated (European Commission, 2003a, 2010a).

Co-existence of supply chains is not a new issue either at the farm level or downstream. Farmers and companies are already involved in segregating production lines, for instance for seed production with high purity levels or for speciality markets, such as waxy maize or double zero rapeseed. However the HGE unit used in the GMO content calculation disturbed many of the companies for a while, because DNA based detection methods were not common in the agricultural and industrial sectors and because the threshold of 1 , then $0.9 \%$, is intermediate between quality thresholds such as those used for cultivars' purity, and safety issues such as those used for avoiding mycotoxins or pathogens.

A general trend of the food industry at the outset of the labelling obligation was to substitute GMO derived products, such as soy lecithin, with related products, such as rapeseed lecithin. With the growing experience of processing companies, these substitutions are no longer relevant, as most of the food and feed industry's recipes are already established for the cheapest and most technologically compatible products.

Because the maintenance of different agricultural production systems is a prerequisite for providing a high degree of consumer choice, a co-existence policy was adopted in the EU in parallel to company stewardships, which is unfortunately not always accurately applied by farmers and companies of GMO exporting countries. This policy specifically aimed at enabling the side-by-side development of different cropping systems without excluding any agricultural option. As such, farmers could maintain their ability to make a practical choice between conventional, organic and GM crops. Since co-existence only applies to approved GM crops that were judged to be safe prior to their commercial release, safety issues fall outside the remit of co-existence (De Schrijver et al., 2007; Devos et al., 2009). Divergent implementation of co-existence rules were carried out by EU Member States, in particular for maize cultivation, as a reflection of different appreciations of the precautionary principle, of scientific results about pollen flows, local pressure from NGOs, as well as producers of signs-of-quality. For instance, Austrian regions banned GMOs from their territory, Germany and France established a new moratorium on Mon810 maize cultivation while, in other Member States, the isolation distances between GM and non-GM fields ranges from $50 \mathrm{~m}$ to $800 \mathrm{~m}$, despite these isolation distances all being supposedly based on the same scientific results (European Commission, 2006, 2009; Levidow and Boschert, 2008; Messéan et al., 2006).

To date there is little experience to draw on for how the new legal co-existence requirements could be practically implemented in the EU in a harmonised manner taking into account local peculiarities. Due to the heterogeneity in farm structures, crop patterns and legal environments between Member States, the European Commission released a very general recommendation for co-existence rules which was, or was not, implemented. Curiously, Spain, the EU Member State with the largest GMO hectarage, did not release co-existence regulations. Coexistence best practice and information systems between farmers have thus to be adapted and implemented at 
national or regional levels. However, the rules already implemented generally consider only feed uses, and thus may not be sufficient for commodities targeting food, that is those directly faced by consumers, or GMOs not to be used in food such as pharmaceuticals and industrial products. Accordingly several regions of EU Member States organised themselves, with or without pre-existing co-existence rules, into GMO-free regional networks (Consmüller et al., 2011; Dalli, 2010; European Committee of the regions, 2007; European Economic and Social Committee, 2005; GMO free European regions network, 2005; Hannachi, 2011; Hermitte, 2006; Schermer, 2001).

However, co-existence at the farm level does not help us to understand whether, how, and at which price, coexistence could be preserved in the remaining links of the supply chain. Results on this issue are absent, although downstream supply chain operators are familiar with segregation issues of products due to their involvement in speciality markets niches. Moreover, the downstream supply chain operators are one of the structuring elements of territories and farmers' organisations. As such their desiderata will clearly influence the co-existence framework, due to targeted market niches or technical issues (Hannachi et al., 2009; Demont et al. 2008). Finally, other requests on agriculture, such as its multifunctionality, the preservation of the environment or states' food sovereignty, are also impacting co-existence schemes (CEA Insurers of Europea, 2009; Devos et al., 2009; European Commission, 2004c; European Committee of the regions, 2007; European Economic and Social Committee, 2005; Marsden, 2008). As such, it was necessary to complement ongoing research into the impact of downstream operators on co-existence at the field level, as was done by Co-Extra.

The two last issues still being discussed consist of the liability and redress issues and who shall or should be in charge of the extra costs entailed by co-existence. AntiGMO stakeholders are requesting that newcomers bear all the new costs of co-existence not only in fields but also at downstream levels. The latter part is not accepted by GMO producers, who consider that the putative premium gained by non-GMO producers would cover the additional traceability and segregation costs.

\subsubsection{European research}

In 1999 the European Commission launched, in the frame of FP5, several research programmes on 'analytical traceability', that is on detection methods aimed preserving the consumers' freedom of choice by accurate labelling.
Those research programmes were not made redundant by national programmes such as the French programme 'Pertinence économique et faisabilité technique des filières OGM et non OGM' (http://www.inra.fr/ genomique/communique7.html). Different scenarios concerning the 0.01 to $5 \%$ labelling threshold were studied for both their technical feasibility and their economic and technical impacts on the agricultural production schemes. The results served as the basis for discussion basis in the EC and EU Member States for establishing the first, 1\%, labelling threshold. Germany, the United Kingdom and other EU Member States also provided important results for traceability and co-existence purposes.

Several EC research programmes, such as DMIFGEN (http://www.dmif-gen.bats.ch/dmif-gen/body.html), QPCRGMOfood (http://www.vetinst.no/eng/Research/ EU-projects/QPCRGMOFOOD) and GMOchips (http:// www.bats.ch/gmochips/) provided the first technical insights into analytical methods and the issues faced in order to reliably detect and quantify the GMO content in products. ENTRANSFOOD, a cluster of research programmes, attempted to gather information from several programmes, and from other parties, but was mostly devoted to risk assessment (Breslin, 2004; European Commission, 2010b; Kuiper et al., 2004).

Most of the members of these research programmes were also members of ENGL (http://gmo-crl.jrc.ec.europa. eu/engl/) which enabled all European Economic Area (EEA) enforcement laboratories to work together under the chair of the European Joint Research Centre (JRC) following its official launch in 2002. They were generally also members of national, CEN and ISO standardisation working groups, ensuring good coordination between research, standardisation and enforcement abilities in developing methods to keep freedom of choice for European consumers.

After the launch in 2002 of the FP6, calls for proposals were launched in Priority 5 (Food safety and quality) which resulted in the research projects SIGMEA (http://www.inra.fr/sigmea), Transcontainer (http://www. transcontainer.wur.nl/uk/) and Co-Extra (www.coextra.eu) with the aim of developing and implementing tools for ensuring co-existence in European supply chains, from seed to retailers' shelves. These European projects were coordinated as far as possible with national projects such as the British Farm Scale Evaluation (http:// www.nerc.ac.uk/press/releases/2003/21a-gmo.asp), German Erprobungsanbau (http://www.coextra.eu/country_reports/ national_projects_DE_en.html) and BMVEL (http://www. gmo-safety.eu/archive/247.next-years-aim-trials-realistic- 
possible.html) or French ANR GCOM2AP (http://w3. jouy.inra.fr/unites/miaj/public/projets/mathrisq/gcom2ap. html) or Mascotte (http://www.inra.fr/les_partenariats/ programmes_anr/programme_ogm/appel_a_projets_ 2007/mascotte) projects.

While SIGMEA mostly focused on field co-existence (Messéan et al. 2009), Trancontainer addressed biocontainment methods. Some of the results of those programmes, whose final reports were recently published by the EC, are included in this book (see the chapters of Squire et al. and De Maagd and Boutillier; De Maagd and Boutilier, 2009a; de Maagd and Boutilier, 2009b; European Commission, 2010b; Messéan et al., 2009).

\subsection{OTHER ISSUES}

In contrast to third countries where the deregulation of GMO is managed by the companies themselves, the EU imposes a post-commercialisation surveillance of health and environmental issues for GMOs approved for importation and cultivation. According to Annex VII of Directive 2001/18/EC, post-market environmental monitoring (PMEM) of genetically modified (GM) plants is a mandatory requirement for applicants, in order to identify possible adverse effects on human health or the environment. Regulation 1829/2003 also makes reference to this directive's annex but in less drastic terms. Guidance note 2002/811/EC provides principles and objectives of the environmental monitoring plan but does not clearly indicate approaches and methods that should be used despite additional precisions provided by EFSA in 2006, that were recently updated after public consultation (EFSA GMO panel, 2006, 2011).

The post-market monitoring addresses both casespecific monitoring (CSM), that is monitoring issues already identified in the risk evaluation work, and general surveillance (GS) on the unexpected effects of GMO commercialisation. The interest in such post-market monitoring can be exemplified by the long term or long distance issues raised by any agricultural innovation (see for instance Fok, 2010; Lu et al., 2010).

At present, EFSA recommendations address only environmental issues, not human and animal health monitoring; a curious situation for a food safety authority.

The EFSA 2011 guidelines changed in 2006 from a 'not hypothesis driven' surveillance scheme, rather similar to biodiversity monitoring, to a more practical, manageable surveillance of indicators and baselines. We can probably see in these changes the effects of a change in the composition of the GMO panel, as well as the trace of lobbying of surveillance agencies of several EU Member States to make surveillance more appropriate to available resources, and maybe also a greater sensitivity towards notifying companies wishing to avoid 'undue' charges. However, the requested surveillance area is restricted to GM fields and their neighbours, which would not permit identification of long distance issues such as those recently reported ( $\mathrm{Lu}$ et al., 2010). The replacement of refuges for avoiding Bt resistant insects by mixtures of GM and non-GM seeds, as foreseen by some seed providers, may also increase the difficulties of specific and general surveillance (Pan et al., 2011). It means that a greater burden will be borne by the EU Member States, whose personnel is generally decreasing, whilst funding is, at the best, kept at the same level with increased duties. This updated version of EFSA guidance takes on board some repeated requests, such as those of the French High Council of Biotechnologies to centralise all data per Member State into inter-connectable databases with geographical information systems (GIS), providing the ability to coordinate results about fields' locations with successive years and multiple event cultivations.

Practically, post-market monitoring is not an easy task. Several national research programmes were launched in the EU and Switzerland, but, despite an abundant literature, there is currently no consensus on a means to address the issue of post-market monitoring (Devos, 2008; Environment Agency Austria Umweltbundesamt, 2011; Hepburn et al., 2008; Pascher et al., 2011; Public Health Agency of Canada, 2002; Sanvido et al., 2007; Sanvido et al., 2005; Wilhelm et al., 2009). In 2011 a European research project on PMEM was launched in an attempt to harmonise them.

Up to now, most of the experience has come from third countries with both CSM as herbicide resistant (super or not) weed apparition in the USA, and surrounding long distance unexpected effects in China (Beckie et al., 2006; Brasher, 2010; Cerdeira and Duke, 2006; Fok, 2010; Kilman, 2010; Lu et al., 2010). To a lesser extent, GMO monitoring reports in Europe generally satisfied EFSA, which is currently studying the last Mon810 monitoring report (Alcalde, 2006; Bartsch et al., 2007; Bayer BioScience N.V., 2008, 2009; Ministerio de medio ambiente y medio rural y marino. Spain, 2010; Monsanto Co., 2006, 2009a, b). However, up to now practical PMEM systems able to retrieve information on slight changes over the long term and long distance are still missing in the EU and third countries despite local efforts and duties (Grossman, 2007; Public Health Agency of Canada, 2002). 


\subsection{CONCLUSION}

The GMO issue, that is the integration of an agricultural innovation and its refusal by several stakeholders, is not inter alia a new issue as several examples of our history, such as the cultivation of hybrid maize in the EU in the 1950s, shows. However, the 'neo-luddite' farmers, as qualified by some authors, in that period appear more in tune with citizens' and consumers' preoccupations, who are looking for more neighbourhood production areas and are frightened by globalisation. Besides some technical issues, such as the dissemination distances of viable pollen, this reluctance towards agricultural innovation is mostly a socio-economic issue which is not the remit of scientists. Some countries use scientific uncertainties in the field of co-existence as a pretext for applying the precautionary principle and managing their public opinion in the growing context of an 'economy of quality'. However, other countries show reluctance to sign up to international treaties that may hurt their companies' exports or finances.

The GMO issue is similar to other international or domestic disputes, such as those on bovine growth hormone or mobile phone dangers, and prefigures, or overlaps, what happens with other innovations such as synthetic biology and nanotechnologies.

We can affirm with certainty that our ability to accurately manage co-existence and traceability of GMOs dedicated to food and feed is necessary for our future capacity to manage GMOs designed for non-food purposes, such as pharmaceuticals, and GMO-designed industry, where the product must not enter food and feed chains.

\section{REFERENCES}

AFP. 2011. L'UE envisage d'interdire les OGM pour éviter des manifestations. In Agence France Presse. Brussels, Belgium. Available at: http://www.agriavis.com/news-38151+ue+envisage+d+interdire+les+ogm+pour+eviter+des+ manifestations.html [accessed 1 May 2012].

Alcalde E. 2006. Post-market monitoring plans of Bt-176 in Spain: 1998-2005. J. Verbrauch. Lebensm., 1: 102-105.

Almli V.L., Verbeke W., Vanhonacker F., Naes T., and Hersleth M. 2011. General image and attribute perceptions of traditional food in six European countries. Food Qual. Prefer, 22: 129-138.

Anonymous. 2008. Nestle CEO asks Europe not to oppose use of GM crops. Available at: http://fbae.org/2009/FBAE/ website/news_nestle-ceo.html [accessed 1 May 2012].

Bartsch D., Buhk H.-J., Engel K.-H., Ewen C., Flachowsky G., Gathmann A., Heinze P., Koziolek C., Leggewie G., Meisner A., Neemann G., Rees U., Scheepers A., Schmidt S., Schulte E., Sinemus K. and Vaasen A. 2009. BEETLE. and the environment (including biodiversity): Prioritisation of potential risks and delimitation of uncertainties. Executive summary and main report. Report to the European Commission (Berlin, DE), pp. 133. Available at: http:// ec.europa.eu/food/food/biotechnology/reports_studies/ docs/lt_effects_report_en.pdf [accessed 1 May 2012].

Bartsch, D., Gathmann, A., Hartley, S., Hendriksen, N.B., Hails, R., Lheureux, K., Kiss, J., Mesdagh, S., Neemann, G., Perry, J., Renckens S., Schiemann J. and Sweet J. 2007. First EFSA experiences with monitoring plans. J. Verbrauch. Lebensm., 2: 33-36.

Bayer BioScience N.V. 2008. Annual report on the general surveillance of MS8, Rf3 and MS8 $\times$ Rf3 in the EU, pp. 10. Available at: http://apps2.bvl.bund.de/bbregwww/ doc.do?id=98 [accessed 1 May 2012].

Bayer BioScience N.V. 2009. Annual report on the general surveillance of MS8, RF3 and MS8 $\times$ RF3 oilseed rape in the EU, pp. 14. Available at: http://apps2.bvl.bund.de/ bbregwww/doc.do?id=201 [accessed 1 May 2012].

BBC Radio4. 2010. Lord Sainsbury calls for new GM debate. Available at: http://news.bbc.co.uk/today/hi/today/newsid_ 8996000/8996870.stm [accessed 1 May 2012].

Beckie H.J., Harker K.N., Hall L.M., Warwick S.I., Legere A., Sikkema P.H., Clayton G.W., Thomas A.G., Leeson J.Y., Seguin-Swartz G. and Symard M.J.. 2006. A decade of herbicide-resistant crops in Canada. Can. J. Plant Sci., 86: $1243-1264$.

Bertheau Y. and Davison J. 2011. Soybean in the European Union, status and perspective. In Soybean/Book 2. D. Krezhova (ed.). Vienna, Austria. Intech Open Access Publisher. In Press.

Bloom J. 2011. Is Europe's ban on Monsanto's GMO crops illegal? In Newsletters. Checkbiotech. Available at: http:// greenbio.checkbiotech.org/news/europes_ban_monsantos_ gmo_crops_illegal [accessed 1 May 2012].

Bonneuil C. and Thomas F. 2009. Genes, Pouvoirs et Profits. Recherche publique et régimes de production des savoirs de Mendel aux OGM. Editions Quae \& Fondation pour le progrès de l'homme. Versailles, France \& Lausanne, Suisse.

Bonny, S. (2003). Why are most Europeans opposed to GMOs? Factors explaining rejection in France and Europe. Electronic Journal of Biotechnology, 6: 50-71.

Bonny S. 2008. How have opinions about GMOs changed over time? The situation in the European Union and the USA. CAB Reviews: Perspectives in Agriculture, Veterinary Science, Nutrition and Natural Resources, 3: $1-17$.

Brasher P. 2010. New weed strategies needed, scientists say. CheckBiotech. Available at: http://checkbiotech.org/node/ 29440/ [accessed 1 May 2012].

Bratspies R.M. 2003. Myths of voluntary compliance: lessons from the Starlink corn fiasco. William \& Mary Environmental Law and Policy Review, 27: 591-647. 
Breslin L. 2004. Food and Chemical Toxicology - Safety assessment, detection and traceability, and societal aspects of genetically modified foods - European Network on Safety Assessment of Genetically Modified Food Crops (ENTRANSFOOD) - Preface. Food Chem. Toxicol., 42: 1043-1043.

Brook Lyndhurst Ltd. 2009. An evidence review of public attitudes to emerging food technologies - A report carried out on behalf of the Social Science Research Unit of the Food Standards Agency (UK). Brook Lyndhurst Ltd. (ed). pp. 89. Available at: http://www.food.gov.uk/multimedia/ pdfs/emergingfoodteches.pdf [accessed 1 May 2012].

Brookes G. and Barfoot P. 2011a. Global impact of biotech crops. Environmental effects 1996-2009. GM Crops, 2: $1-16$.

Brookes G. and Barfoot P. 2011b. GM crops: global socioeconomic and environmental impacts 1996-2009, U. PG Economics Ltd (ed.), pp. 173. Available at: http:// www.pgeconomics.co.uk/pdf/2011 globalimpactstudy.pdf [accessed 1 May 2012].

Brown E., Dury S. and Holdsworth M. 2009. Motivations of consumers that use local, organic fruit and vegetable box schemes in Central England and Southern France. Appetite, 53: $183-188$

Bütschi D., Gram S., Haugen J.M., Meyer R., Sauter A., Steyaert S. and Torgersen H. 2009. Genetically modified plants and foods. Challenges and future issues in Europe, E.P.T. Assessment, (ed.). Berlin, Germany. pp. 108. Available at: http://www.itas.fzk.de/deu/lit/2009/buua09a.pdf [accessed 1 May 2012].

CEA Insurers of Europea. 2009. Navigating the environmental liability directive. A practical guide for insurance underwriters and claims handlers. April 2009, CEA (ed.), pp. 76. Available at: http://www.cea.eu/uploads/Modules/ Publications/1240585425_eld-best-practice-guide-update. pdf [accessed 1 May 2012].

Cerdeira A.L. and Duke S.O. 2006. The current status and environmental impacts of glyphosate-resistant crops: A review. J. Environ. Qual., 35: 1633-1658.

Chambers S., Lobb A., Butler L., Harvey K. and Traill W.B. 2007. Local, national and imported foods: A qualitative study. Appetite, 49: 208-213.

Chen M., Shelton A. and Ye G.-Y. 2011. Insect-resistant genetically modified rice in China: from research to commercialization. Ann. Rev. Entomol., 56: 81-101.

Chiffoleau, Y. 2009. From politics to co-operation: the dynamics of embeddedness in alternative food supply chains. Sociol. Ruralis, 49: 218-235.

Cohan F.M. 2010. Synthetic biology: now that we're creators, what should we create? Curr. Bio., 20: R675-R677.

Consmüller N., Beckmann V. and Petrick M. 2011. Towards GMO-free landscapes? Identifying driving factors for the establishment of cooperative GMO-free zones in Germany. Paper presented at: Vortrag anlässlich der 51 Jahresta- gung der GEWISOLA, Unternehmerische Landwirtschaft zwischen Marktanforderungen und gesellschaftlichen Erwartungen. Halle, Germany. 28-30 September 2011.

Consumerchoice Consortium. 2008. Do European consumers buy GM foods? European Commission: Framework 6, Project no. 518435. Consumerchoice's final report, pp. 346. Available at: http://www.kcl.ac.uk/schools/biohealth/ research/nutritional/consumerchoice/downloads.html [accessed 1 May 2012].

Cowan T. 2011. Agricultural biotechnology: background and recent issues. In CRS Report for the Congress. Congress Report Service (ed.). Washington DC, USA. pp. 46. Available at: http://infousa.state.gov/economy/industry/ docs/73949.pdf [accessed 1 May 2012].

Dalli J. 2010. Where do we stand? In 6th European Conference of GMO-free Regions, European Commission (ed.). Brussels, Belgium. Available at: http://europa.eu/rapid/ pressReleasesAction.do?reference=SPEECH/10/443\&for mat=HTML [accessed 1 May 2012].

Davison J. 2010. GM plants: science, politics and EC regulations. Plant Sci., 178: 94-98.

Davison J. and Bertheau Y. 2007. EU regulations on the traceability and detection of GMOs: difficulties in interpretation, implementation and compliance. CAB Reviews: Perspectives in Agriculture, Veterinary Science, Nutrition and Natural Resources, 2: 14 pp.

Davison J. and Bertheau Y. 2008. The theory and practice of European traceability regulations for GM food and feed. Cereal Foods World, 53: 186-196.

Davison J. and Bertheau Y. 2010. Genetically modified organisms (GMOs): authorized, unauthorized and unknown. Encyclopedia of Biotechnology in Agriculture and Food, $\mathbf{1}$ : 301-305.

de Cheveigné S. 2004. Quand l'Europe mesure les représentations de la science : une analyse critique des Eurobaromètres. In: J.L. Marec and I. Babou (eds). Sciences, Médias et Société. Lyon, France. Ecole normale supérieure. Lettres et Sciences Humaines. Laboratoire JE 2419. Communication, culture et société. pp. 45-55.

de Jonge J., van Trijp H., Renes R.J. and Frewer L. 2007. Understanding consumer confidence in the safety of food: Its two-dimensional structure and determinants. Risk Anal., 27: 729-740.

de Maagd R. and Boutilier K. 2009a. Efficacy of strategies for biological containment of transgenic crops. A literature review. COGEM (ed.). pp. 62. Available at: http://www. cogem.net/ContentFiles/2010-01\%20biologische\%20 inperkingsmaatregelen1.pdf [accessed 1 May 2012].

de Maagd R.A. and Boutilier K. 2009b. TransContainer: overview and progress. Paper presented at: Co-Extra international conference. Paris, France. 3-4 June 2009. Available at: http://www.inra.fr/content/download/16700/276597/ version/1/file/Co-Extra-Conference-Book-final-low-res. pdf [accessed 1 May 2012]. 
De Schrijver A., Devos Y., Van den Bulcke M., Cadot P., De Loose M., Reheul D. and Sneyers, M. 2007. Risk assessment of GM stacked events obtained from crosses between GM events. Trends Food Sci. Tech., 18: 101-109.

DeLind L.B. 2011. Are local food and the local food movement taking us where we want to go? Or are we hitching our wagons to the wrong stars? Agr. Hum. Values, 28: 273-283.

Demont M., Daems W., Dillen K., Mathijs E., Sausse C. and Tollens E. 2008. Regulating coexistence in Europe: beware of the domino-effect! Ecol. Econ., 64: 683-689.

Devos Y., Demont M., Dillen K., Reheul D., Kaiser M. and Sanvido O. 2009. Coexistence of genetically modified (GM) and non-GM crops in the European Union. A review. Agron. Sustain. Dev., 29: 11-30.

Devos Y., Maeseele P., Reheul D., Van Speybroeck L. and De Waele D. 2008. Ethics in the societal debate on genetically modified organisms: a (re)quest for sense and sensibility. J. Agr. Environ. Ethic., 21: 29-61.

Devos Y., Reheul D., De Waele D. and Van Speybroeck L. 2006. The interplay between societal concerns and the regulatory frame on GM crops in the European Union. Environmental Biosafety Research, 5: 127-149.

Devos Y.A. 2008. Transgenic crops: a kaleidoscope impact analysis. In Department of plant production, faculty of bioscience engineering of the Ghent University. Ghent, Belgium. pp. 342. Available at: http://www.criticalphilosophy. ugent.be/index.php?id=2\&type=file [accessed 1 May 2012].

Dunmore C. and Toyer J. 2011. EU court says French GM maize ban was illegal. Reuters News. Available at: http://uk.reuters.com/article/2011/09/08/uk-eu-court-gmoidUKTRE7873Y920110908 [accessed 1 May 2012].

Durant R.F. and Legge J.S. 2005. Public opinion, risk perceptions, and genetically modified food regulatory policy Reassessing the calculus of dissent among European citizens. Eur. Union Polit., 6: 181-200.

Durant R.F. and Legge J.S. 2006. 'Wicked problems', public policy, and administrative theory - Lessons from the GM food regulatory arena. Admin. Soc., 38: 309-334.

Editorial 2011. Growing pains. It is time to update decadesold regulation of genetically engineered crops. Nature, $\mathbf{4 7 5}$ : 265-266.

EFSA GMO Panel. 2006. Opinion of the scientific panel on genetically modified organisms on the post market environmental monitoring (PMEM) of genetically modified plants (Question No EFSA-Q-2004-061). The EFSA Journal, 319: $1-27$.

EFSA GMO Panel. 2011. Guidance on the Post-Market Environmental Monitoring (PMEM) of genetically modified plants. The EFSA Journal, 9: 2316.

Environment Agency Austria Umweltbundesamt. 2011. Monitoring of genetically modified organisms. A joint policy paper by BfN (Germany), FOEN (Switzerland) and EEA
Austria (ed.). pp. 58. Available at: http://www.bfn.de/ fileadmin/MDB/documents/presse/REP0305_1.pdf [accessed 1 May 2012].

Ervin D.E., Glenna L.L. and Jussaume Jr. R.A. 2011. The theory and practice of genetically engineered crops and agricultural sustainability. Sustainability, 3: 847-874.

Esposito V. and Kolodinsky J. 2007. Consumer attitudes and policy directions for GM labeling and pollen drift regulation: evidence from the 2006 Vermonter Poll. AgBioForum, 10: 85-93.

European Commission. 2000. Commission regulation (EC) No 49/2000 of 10 January 2000 amending Council Regulation (EC) No 1139/98 concerning the compulsory indication on the labelling of certain foodstuffs produced from genetically modified organisms of particulars other than those provided for in Directive 79/112/EEC. Official Journal of the European Communities, L 6: 13-14.

European Commission. 2002. Regulation (EC) No 178/2002 of the European Parliament and of the Council of 28 January2002 laying down the general principles and requirements of food law, establishing the European Food Safety Authority and laying down procedures in matters of food safety. Official Journal of the European Communities, L 31: 1-24.

European Commission. 2003a. Commission Recommendation of 23 July 2003 on guidelines for the development of national strategies and best practices to ensure the coexistence of genetically modified crops with conventional and organic farming (notified under document number C(2003) 2624). (2003/556/CE). Official Journal of the European Communities, L 189: 36-47.

European Commission. 2003b. Regulation (EC) No 1830/2003 of the European Parliament and of the Council of 22 September 2003 concerning the traceability and labelling of genetically modified organisms and the traceability of food and feed products produced from genetically modified organisms and amending Directive 2001/18/EC. Official Journal of the European Union, L 268: 24-28.

European Commission. 2003c. Regulation (EC) No 1946/2003 of the European Parliament and of the Council of 15 July 2003 on transboundary movements of genetically modified organisms. Official Journal of the European Union, L 287: $1-10$.

European Commission. 2004a. Commission recommendation No 2004/787 of 4 october 2004 on technical guidance for sampling and detection of genetically modified organisms as or in products in the context of Regulation (EC) No 1830/2003. Official Journal of the European Union, L 348: $18-26$.

European Commission. 2004b. Commission regulation (EC) No 641/2004 of 6 April 2004 on detailed rules for the implementation of Regulation (EC) No 1829/2003 of the European Parliament and of the Council as regards the application for the authorisation of new genetically 
modified food and feed, the notification of existing products and adventitious or technically unavoidable presence of genetically modified material which has benefited from a favourable risk evaluation. Official Journal of the European Union, L 102: 14-25.

European Commission. 2004c. Directive 2004/35/CE of the European Parliament and of the Council of 21 April 2004 on environmental liability with regard to the prevention and remedying of environmental damage. Official Journal of the European Union, L 143: 56-75.

European Commission. 2004d. Regulation (EC) No 882/2004 of the European Parliament and of the Council of 29 April 2004 on official controls performed to ensure the verification of compliance with feed and food law, animal health and animal welfare rules. Official Jounal of the European Union, L 165: 1-141.

European Commission. 2005. Commission decision No. 2005/317/EC of 18 April 2005 on emergency measures regarding the non-authorised genetically modified organism Bt10 in maize products. Official Journal of the European Union, L 101: 14-16.

European Commission. 2006. Communication from the Commission to the Council and the European Parliament. Report on the implementation of national measures on the coexistence of genetically modified crops with conventional and organic farming. \{SEC(2006) 313\}. COM/2006/0104 final, pp. 10. Available at: http://ec.europa.eu/agriculture/ coexistence/com104_en.pdf [accessed 1 May 2012].

European Commission. 2007. Council Regulation (EC) No $834 / 2007$ of 28 June 2007 on organic production and labelling of organic products and repealing Regulation (EEC) No 2092/91. Official Jounal of the European Union, L 189: $1-23$.

European Commission. 2008a. Attitudes of European citizens towards the environment. In Eurobarometer, Special Eurobarometer 295.Wave. 68.2., European Commission. DG ENV DG COM (ed.), pp. 127.

European Commission. 2008b. Commission decision of 3 April 2008 on emergency measures regarding the unauthorised genetically modified organism ' $\mathrm{Bt} 63$ ' in rice products. Official Journal of the European Union, L 096: 29-34.

European Commission. 2008c. Report from the Commission to the Council and the European Parliament on the implementation of Regulation (EC) No 1830/2003 concerning the traceability and labelling of genetically modified organisms and the traceability of food and feed products produced from genetically modified organisms and amending Directive 2001/18/EC. COM (2008) 560 final. pp. 11. Available at: http://eur-lex.europa.eu/ LexUriServ/LexUriServ.do?uri=COM:2008:0560:FIN:EN: PDF [accessed 1 May 2012].

European Commission. 2009. Report from the Commission to the Council and the European Parliament on the coexistence of genetically modified crops with conventional and organic farming (SEK(2009) 408). COM/ 2009 / 0153 final, European Commission (ed.), pp. 12. Available at: http:// eur-lex.europa.eu/LexUriServ/LexUriServ.do?uri=COM:2 009:0153:FIN:EN:PDF [accessed 1 May 2012].

European Commission. 2010a. Commission Recommendation of 13 July 2010 on guidelines for the development of national co-existence measures to avoid the unintended presence of GMOs in conventional and organic crops (2010/C 200/01). Official Journal of the European Union, C 200: 1-5.

European Commission. 2010b. A decade of EU-funded GMO research (2001-2010). EUR 24473, European Commission (ed.). Brussels, Belgium. pp. 264. Available at: http:// ec.europa.eu/research/biosociety/pdf/a_decade_of_eufunded_gmo_research.pdf [accessed 1 May 2012].

European Commission. 2011. Report from the Commission to the European parliament and the Council on socioeconomic implications of GMO cultivation on the basis of Member States contributions, as requested by the Conclusions of the Environment Council of December 2008. SANCO/10715/2011 Rev. 5 (POOL/E1/2011/10715/ 10715R5-EN.doc). Brussels, Belgium. Pp 11. Available at: http://ec.europa.eu/food/food/biotechnology/reports_studies/ docs/socio_economic_report_GMO_fr.pdf [accessed 1 May 2012].

European Commission. DG SANCO. 2011. Review of Regulation (EC) No 882/2004 on official controls on food and feed safety, animal health and animal welfare. pp. 5. Available at: http://ec.europa.eu/governance/impact/planned_ia/ docs/2011_sanco_011_food_chain_en.pdf [accessed 1 May 2012].

European Committee of the Regions. 2007. Opinion of the Committee of the Regions on the Communication from the Commission to the Council and the European Parliament Report on the implementation of national measures on the coexistence of genetically modified crops with conventional and organic farming. Official Journal of the European Union, C 57/3: 11-18.

European Economic and Social Committee. 2005. Opinion of the European Economic and Social Committee on the 'Coexistence between genetically modified crops, and conventional and organic crops'. Official Journal of the European Union, C 157: 155-166.

Felt U. and Fochler M. 2008. The bottom-up meanings of the concept of public participation in science and technology. Science and Public Policy, 35: 489-499.

Ferretti M.P. and Pavone V. 2009. What do civil society organisations expect from participation in science? Lessons from Germany and Spain on the issue of GMOs. Science and Public Policy, 36: 287-299.

Finucane M.L. 2002. Mad cows, mad corn and mad communities: the role of socio-cultural factors in the perceived risk of genetically-modified food. P. Nutr. Soc., 61 : $31-37$. 
Finucane M.L. and Holup J.L. 2005. Psychosocial and cultural factors affecting the perceived risk of genetically modified food: an overview of the literature. Soc. Sci. Med., 60: 1603-1612.

Fok M. 2010. Gone with the wind of transgenic cotton use in the United States. A vision of the discussions and presentations at the New Orleans (Louisiana, USA) "Beltwide Cotton Conferences" in January 2010. Cahiers Agricultures, 19: 292-298.

Food Chain Evaluation Consortium. 2009. Evaluation of the EU legislative framework in the field of GM food and feed. Inception report submitted by Food Chain Evaluation Consortium (FCEC), Civic Consulting, Agra CEAS Consulting, Van Dijk Management Consultants, Arcadia international. Brussels, Belgium, pp. 47. Available at: http:// ec.europa.eu/food/food/biotechnology/evaluation/docs/ GMO_September_progress_report_en.pdf [accessed 1 May 2012].

Fox J.L. 2003. Puzzling industry response to ProdiGene fiasco. Nat. Biotechnol., 21: 3-4.

Fox J.L. (2011). Bayer's GM rice defeat. Nat. Biotechnol., 29: $473-473$.

Frewer L.J., Bergmann K., Brennan M., Lion R., Meertens R., Rowe G., Siegrist M. and Vereijken, C. 2011. Consumer response to novel agri-food technologies: implications for predicting consumer acceptance of emerging food technologies. Trends Food Sci. Tech., 22: 442-456.

Frewer L.J., Hunt S., Brennan M., Kuznesof S., Ness M. and Ritson C. 2003a. The views of scientific experts on how the public conceptualize uncertainty. J. Risk Res., 6: 75-85.

Frewer L.J., Scholderer J. and Bredahl L. 2003b. Communicating about the risks and benefits of genetically modified foods: The mediating role of trust. Risk Anal., 23: 1117-1133.

Frewer L.J., Lassen J., Kettlitz B., Scholderer J., Beekman V. and Berdal K.G. 2004. Societal aspects of genetically modified foods. Food Chem. Toxicol., 42: 1181-1193.

Frizzi A., and Huang S.S. 2010. Tapping RNA silencing pathways for plant biotechnology. Plant Biotechnol. J., 8: 655-677.

GAO (US General Accouting Office). 2011. Homeland security: actions needed to improve response to potential terrorist attacks and natural disasters affecting food and agriculture, US General Accounting Office (ed.). Washington, DC, USA. pp. 81. Available at: http://www.gao.gov/ new.items/d11652.pdf [accessed 1 May 2012].

Gaskell G., Allansdottir A., Allum N., Corchero C., Fischler C., Hampel J., Jackson J., Kronberger N., Mejlgaard N., Revuelta G., C. Schreiner, S. Stares, H. Torgersen and W. Wagner. 2006. Europeans and Biotechnology in 2005: patterns and trends. Eurobarometer 64.3. A report to the European Commission's Directorate-General for Research. In Eurobarometer. European Commission (ed.). Brussels, 2006-jul-eurobarometro-bio-2nd-ed.pdf [accessed 1 May 2012].

Gaskell G., Allum N. and Stares S. 2003. Europeans and Biotechnology in 2002. Eurobarometer 58.0. A report to the EC Directorate General for Research from the project 'Life Sciences in European Society' QLG7-CT-1999-00286, pp. 44. Available at: http://www.keine-gentechnik.de/bibliothek/ basis/studien/eurobaromenter_europeans_biotechnology_ 010303.pdf [accessed 1 May 2012].

Gaskell G., Stares S., Allansdottir A., Allum N., Castro P., Esmer Y., Fischler C., Jackson J., Kronberger N., Hampel J., N. Mejlgaard, A. Quintanilha, A. Rammer, G. Revuelta, P. Stoneman, H. Torgersen and W. Wagner. 2010. Europeans and biotechnology in 2010. Winds of change? A report to the European Commission's Directorate-General for Research. EUR 24537 EN. In Research*eu Studies and reports. Brussels, Belgium. pp. 176. Available at: http:// ec.europa.eu/public_opinion/archives/ebs/ebs_341_winds_ en.pdf [accessed 1 May 2012].

Gassmann A.J., Petzold-Maxwell J.L., Keweshan R.S. and M.W. Dunbar. 2011. Field-evolved resistance to Bt maize by western corn rootworm. PLOS ONE, 6: e22629.

Glick B.R., Pasternak J.J. and Patten C.L. (eds). 2010. Molecular Biotechnology: Principles and Applications of Recombinant DNA. 4th edition. ASM Press, Washington DC.

GMO free European regions network. 2005. Network's technical proposals on coexistence between GM and conventional and organic agricultures, GMO. Free European Region Network (ed.). pp. 6. Available at: http:// www.gmofree-euregions.net:8080/docs/ajax/ogm/Networkposition-on-coexistence_TECHNICAL-contribution_EN. pdf [accessed 1 May 2012].

Granjou C. and Valceschini, E. (2004). Certifying in a context of uncertainty: the case of GMOs. Natures Sciences Sociétés, 12: 404-412.

Grossman M.R. 2005. Traceability and labeling of genetically modified crops, food, and feed in the European Union. Journal of Food Law \& Policy, 44: 43-85.

Grossman M.R. 2007. Genetically modified food and feed and the US national environment policy Act. European Food and Feed Law Review, 6: 373-377.

Guehlstorf N.P. 2008. Understanding the scope of farmer perceptions of risk: considering farmer opinions on the use of genetically modified (GM) crops as a stakeholder voice in policy. J. Agr. Environ. Ethic., 21: 541-558.

Guehlstorf N.P. and Hallstrom L.K. 2005. The role of culture in risk regulations: a comparative case study of genetically modified corn in the United States of America and European Union. Environ. Sci. Policy, 8: 327-342.

Guerrero L., Guardia M.D., Xicola J., Verbeke W., Vanhonacker F., Zakowska-Biemans S., Sajdakowska M., Sulmont-Rosse C., Issanchou S., Contel M., Scalvedi M. L., Granli B. S. and Hersleth M. 2009. Consumer-driven definition of traditional food products and innovation 
in traditional foods. A qualitative cross-cultural study. Appetite, 52: 345-354.

Hannachi M. 2011. La coopétition au service du bien commun. Les stratégies des entreprises de collecte et de stockage de céréales face aux OGM. In: Ecole doctorale CRIT: Culture, régulation, institutions et territoire (Versailles, Université de Versailles Saint-Quentin-en-Yvelines), pp. 302. Available at: http://www.inra.fr/sciences_action_ developpement/content/download/4333/45120/version/1/ file/These_Hannachi_2011.pdf [accessed 1 May 2012].

Hannachi M., Coléno F.C. and Assens C. 2009. Collective strategies and coordination for the management of coexistence: the case studies of Alsace and western South of France. Paper presented at Fourth International Conference on Coexistence between Genetically Modified (GM) and non-GM based Agricultural Supply Chains (Melbourne, Australia). Available at: http://assens.perso.neuf.fr/ GMO2009.pdf [accessed 1 May 2012].

Henry C., Hugo S., Blackburn J. and Nicholls D. 2006. Cumulative long-term effects of genetically modified (GM) crops on human/animal health and the environment: risk assessment methodologies. Report to the European Commission. pp. 236. Available at: http://ec.europa.eu/food/ food/biotechnology/reports_studies/docs/report_lt_effects_ 2006_en.pdf [accessed 1 May 2012].

Hepburn P., Howlett J., Boeing H., Cockburn A., Constable A., Davi A., de Jong N., Moseley B., Oberdorfer R., Robertson C., Wal J.M. and Samuels F. 2008. The application of post-market monitoring to novel foods. Food Chem. Toxicol., 46: 9-33.

Hermitte M.-A. 2006. Chapitre 3. Les zones sans plantes génétiquement modifiées en droit européen. L'illégalité comme stratégie juridique. Journal International de Bioéthique, 17: 1-26.

Hilson C. 2005. Information disclosure and the regulation of traded product risks. J. Environ. Law, 17: 305-322.

Hladky G.B. 2011. The surprisingly complex debate over whether Genetically Modified foods should be labeled. CheckBiotech, 30 March 2011. Available at: http://greenbio. checkbiotech.org/news/surprisingly_complex_debate_ over_whether_genetically_modified_foods_should_be labeled [accessed 1 May 2012].

Hoban T.J. 2004. Public attitudes towards agricultural biotechnology. In ESA working papers. Agricultural and Development Economics Division. The Food and Agriculture Organization of the United Nations (ed.). pp. 16. Available at: http://croplifeasia.org/ref_library/biotechnology/ public_att_biotech_hoban.pdf [accessed 1 May 2012].

Hogg T.A., Couto J.A., Teixeira P. and Malcata F.X. 2008. Building on scientific excellence via sharing of scientific expertise - The case study of food safety. Trends Food Sci. Tech., 19: S9-S13.

Holst-Jensen A. and Berdal K.G. 2004. The modular analytical procedure and validation approach and the units of measurement for genetically modified materials in foods and feeds. J. AOAC Intl., 87: 927-936.

Hoorfar J., Jordan K., Butler F. and Prugger R. (eds). 2011. Food Chain Integrity. A Holistic Approach to Food Traceability, Safety, Quality and Authenticity. Woodhead Publishing Ltd. Oxford, Cambridge, Philadephia, New Delhi, pp. 360.

Hoppe R.A. and Banker D.E. 2010. Structure and finances of U.S. farms. Family farm report, 2010 Edition. US Department of Agriculture (ed.). pp. 72. Available at: http://www.ers.usda.gov/Publications/EIB66/EIB66.pdf [accessed 1 May 2012].

Hoppe R.A., Korb P.J., O’Donoghue E.J. and Banker D.E. 2007. Structure and finances of U.S. farms: family farm report, 2007 Edition. US Department of Agriculture (ed.). pp. 58. Available at: http://ageconsearch.umn.edu/handle/ 59032 [accessed 1 May 2012].

House L., Lusk J., Jaeger S., Traill W.B. and Moore M. 2003. Objective and subjective knowledge: impacts on consumer demand for genetically modified foods in the United States and the European Union. AgBioForum, 7: 113. Available at: http://www.agbioforum.org/v7n3/v7n3a03-house.htm [accessed 1 May 2012].

Hwang Y.J., Roe B. and Teisl M.F. 2005. An empirical analysis of United States consumers' concerns about eight food production and processing technologies. AgBioForum, 8: 40. Available at: http://www.agbioforum.org/v8n1/v8n1a06roe.pdf [accessed 1 May 2012].

Jacobsen E. and Schouten H.J. 2009. Cisgenesis: an important sub-invention for traditional plant breeding companies. Euphytica, 170: 235-247.

James C. 2011. Global status of commercialized biotech / GM crops: 2010. In ISAAA Brief. ISAAA, (ed.). Ithaca, NY, USA. Available at: http://www.isaaa.org/resources/ publications/briefs/42/executivesummary/default.asp [accessed 1 May 2012].

James J.S. 2004. Consumer knowledge and acceptance of agricultural biotechnology vary. Calif. Agr., 58: 99-105.

Kanter J. 2010. E.U. signals big shift on genetically modified crops. In The New-York Times. New-York, USA. Available at: http://www.nytimes.com/2010/05/10/business/energyenvironment/10green.html?_r=1\&src=busln [accessed 1 May 2012].

Kaphengst T., El Benni N., Evans C., Finger R., Herbert S., Morse S. and Stupak N. 2011. Assessment of the economic performance of GM crops worldwide. Report to the European Commission, pp. 149. Available at: http://ec.europa.eu/ food/food/biotechnology/reports_studies/docs/economic_ performance_report_en.pdf [accessed 1 May 2012].

Kay S. and Paoletti C. 2001. Sampling strategies for GMO detection and/or quantification, JRC-IHCP (ed.). pp. 16. http://mbg.jrc.ec.europa.eu/ [accessed 1 May 2012].

Kilman S. 2010. Superweed outbreak triggers arms race. In: The Wall Stree Journal. 4th June 2010. New York, 
USA. Available at: http://www.neurologicalhealth.org/pdf/ Superweed $\% 20$ Outbreak $\% 20$ Triggers $\% 20$ Arms $\% 20$ Race.pdf [accessed 1 May 2012].

Kleinman D.L. and Kinchy A.J. 2007. Against the neoliberal steamroller? The Biosafety Protocol and the social regulation of agricultural biotechnologies. Agr. Hum. Values, 24: 195-206.

Kleinman D.L. and Kloppenburg J. 1991. Aiming for the discursive high ground: Monsanto and the biotechnology controversy. Sociol. Forum, 6: 427-447.

Kuiper H.A., Konig A., Kleter G.A., Hammes W.P. and Knudsen I. 2004. Food and chemical toxicology - Concluding remarks. Food Chem. Toxicol., 42: 1195-1202.

Kurzer P. and Cooper A. 2007a. Consumer activism, EU institutions and global markets: the struggle over biotech foods. J. Public Policy, 27: 103-128.

Kurzer P. and Cooper A. 2007b. What's for dinner? - European farming and food traditions confront American biotechnology. Comp. Polit. Stud., 40: 1035-1058.

Ledford H. 2011. Transgenic grass skirts regulators. Technological advances remove basis for government oversight of genetically modified crops. Nature, 274: 274-275.

Levidow L. 2007. European public participation as risk governance: enhancing democratic accountability for agbiotech policy? East Asian Science, Technology and Society: An International Journal, 1: 19-51.

Levidow L. and Boschert K. 2008. Coexistence or contradiction? GM crops versus alternative agricultures in Europe. Geoforum, 39: 174-190.

Levidow L. and Carr S. 1997. How biotechnology regulation sets a risk/ethics boundary. Agr. Hum. Values, 14: 29-43.

Levidow L., Murphy J. and Carr S. 2007. Recasting 'Substantial equivalence' - Transatlantic governance of GM food. Sci. Technol. Hum. Values, 32: 26-64.

Li Y.R., Wailes E.J., McKenzie A. and Thomsen M. 2010. LL601 contamination and its impact on U.S. rice prices. J. Agr. Appl. Econ., 42: 31-38.

Lien M.E. and Anthony R. 2007. Special Issue: Ethics and the politics of food. J. Agr. Environ. Ethic., 20: 411-508.

Lisbet B. 2004. Trust in food in the age of mad cow disease: a comparative study of consumers' evaluation of food safety in Belgium, Britain and Norway. Appetite, 42: 21-32.

Lockie S., Lawrence G., Lyons K. and Grice J. 2005. Factors underlying support or opposition to biotechnology among Australian food consumers and implications for retailer-led food regulation. Food Policy, 30: 399-418.

Löfstedt R.E. 2004. The swing of the regulatory pendulum in Europe: from Precautionary Principle to (regulatory) impact analysis. J. Risk Uncertainty, 28: 237-260.

Lu Y., Wu K., Jiang Y., Xia B., Li P., Feng H., Wyckhuys K.A.G. and Guo Y. 2010. Mirid bug outbreaks in multiple crops correlated with wide-scale adoption of Bt cotton in China. Science, 328: 1151-1154.
Lusser M., Parisi C., Plan D. and Rodríguez-Cerezo E. 2011. New plant breeding techniques. State-of-the-art and prospects for commercial development. EUR $24760 \mathrm{EN}$. JRC-IPTS, European Commission (ed.). pp. 220. Available at: ftp://ftp.jrc.es/pub/EURdoc/JRC63971.pdf [accessed 1 May 2012].

Marette S., Clemens R. and Babcock B.A. 2007. The recent international and regulatory decisions about geographical indications. In: MATRIC Working Paper 07-MWP 10. pp. 35. And: Agribusiness, 24(4): 453-472.

Marette S., Roosen J., Bieberstein A., Blanchemanche S. and Vandermoere, F. 2009. Impact of environmental, societal and health information on consumers' choices for nanofood. Journal of Agricultural \& Food Industrial Organization, 7: Article 11.

Marris C., Ronda S., Bonneuil C. and Joly P.-B. 2004. National Report - France. Battling with Expertise, pp. 100. Available at: http://technology.open.ac.uk/cts/national/ france\%20national\%20report\%20PEG.pdf [accessed 1 May 2012].

Marris C., Wynne B., Simmons P. and Weldon S. 2001. Final Report of the PABE research project funded by the Commission of European Communities. Contract number: FAIR CT98-3844 (DG12-SSMI), pp. 113. Available at: http:// csec.lancs.ac.uk/archive/pabe/docs/pabe_finalreport.pdf [accessed 1 May 2012].

Marsden T. 2008. Agri-food contestations in rural space: GM in its regulatory context. Geoforum, 39: 191-203.

Meghani Z. 2009. The US' Food and Drug Administration, normativity of risk assessment, GMOs, and American democracy. J. Agr. Environ. Ethic., 22: 125-139.

Meghani Z. and Kuzma, J. 2011. The 'Revolving Door' between regulatroy agencies and industry: a problem that requires reconceptualizing objectivity. J. Agr. Environ. Ethic., 24(6): 575-599.

Messéan A., Angevin F., Gomez-Barbero M., Menrad K. and Rodriguez-Cerezo E. 2006. New case studies on the coexistence of GM and non-GM crops in European agriculture. EUR22102 EN, JRC-IPTS (ed.). Seville, Spain. pp. 116. Available at: http://www.jrc.es/home/pages/ eur22102enfinal.pdf [accessed 1 May 2012].

Messéan A., Squire G., Perry J., Angevin F., Gomez M., Townend P., Sausse C., Breckling B., Langrell S., Dzeroski, S. and Sweet J. 2009. Sustainable introduction of GM crops into european agriculture: a summary report of the FP6 SIGMEA research project. OCL - Ol. Corps Gras Li., 16: $37-51$.

Miller H.I. 2010. Split approvals and hot potatoes. Nat. Biotechnol., 28: 552-553.

Miller H.I. and Conko G. (eds.) 2004. The Frankenfood myth: how protest and politics threaten the biotech revolution. ABC-CLIo Inc. pp xxI+269.

Ministerio de medio ambiente y medio rural y marino. Spain. 2010. Planes de seguimiento ambiental del cultiva de maiz 
modificado geneticamente en España. pp. 72. Available at: http://www.marm.es/es/calidad-y-evaluacion-ambiental/ temas/biotecnologia/PLAN_DE_SEGUIMIENTO_mar_ 2011_tcm7-147305.pdf [accessed 1 May 2012].

Mirouze M. and Paszkowski, J. (2011). Epigenetic contribution to stress adaptation in plants. Curr. Opin. Plant Biol., 14: $267-274$.

Monsanto Co. 2006. Monitoring report. Mon810 cultivation. Czech republic, France, Germany, Portugal and Spain. 2005. pp. 236. Available at: https://yieldgard.eu [accessed 1 May 2012].

Monsanto Co. 2009a. Annual monitoring report on the cultivation of MON 810 in 2008. Czech Republic, Germany, Portugal, Slovakia, Poland, Romania and Spain, pp. 388. Available at: https://yieldgard.eu [accessed 1 May 2012]

Monsanto Co. (2009b). Monitoring report. MON 810 cultivation. Spain. 2003-2004, pp. 57. Available at: https:// yieldgard.eu [accessed 1 May 2012].

Moore A. 2010. Public bioethics and deliberative democracy. Polit. Stud.-London, 58: 715-730.

Newell P. 2003. Globalization and the governance of biotechnology. Global Environ. Polit., 3: 56-71.

Nie C. and Zepeda L. 2011. Lifestyle segmentation of US food shoppers to examine organic and local food consumption. Appetite, 57: 28-37.

Noble D.F. 1983. Presente tense technology. Democracy, 3: 8-24.

Noussair C., Robin S. and Ruffieux B. 2001a. Consumer behaviour with regard to GMOs in the food supply: an experimental study. Economie Rurale, 266: 30-44.

Noussair C., Robin S. and Ruffieux B. 2001b. Genetically modified organisms in the food supply: public opinion $v s$. consumer behavior. Purdue University Economics Working Papers 1139. Available at: http://ideas.repec.org/p/pur/ prukra/1139.html [accessed 1 May 2012].

Noussair C., Robin S. and Ruffieux, B. 2002. Do consumers not care about biotech foods or do they just not read the labels? Econ. Lett., 75: 47-53.

Noussair C., Robin S. and Ruffieux B. 2004. Revealing consumers' willingness-to-pay: A comparison of the BDM mechanism and the Vickrey auction. Journal of Economic Psychology, 25: 725-741.

Oosterveer P. 2007. Global Governance of Food Production and Consumption: Issues and Challenges. Global Governance of Food Production and Cconsumption: Issues and Challenges. Edward Elgar Publishing, Cheltenham.

PA 2010. Ex-minister Lord Sainsbury of Turville urges fresh debate on GM crops. Available at: http://www.independent. co.uk/environment/green-living/exminister-lord-sainsburyof-turville-urges-fresh-debate-on-gm-crops-2078587.html [accessed 1 May 2012].

Pan Z.Q., Onstad D.W., Nowatzki T.M., Stanley B.H., Meinke L.J. and Flexner J.L. 2011. Western Corn Rootworm (Coleoptera: Chrysomelidae) dispersal and adaptation to single- toxin transgenic corn deployed with block or blended refuge. Environ. Entomol., 40: 964-978.

Paoletti C., Donatelli M., Kay S. and Van den Eede G. 2003. Simulating kernel lot sampling: the effect of heterogeneity on the detection of GMO contaminations. Seed Sci. Technol., 31: 629-638.

Paoletti C., Heissenberger A., Mazzara M., Larcher S., Grazioli E., Corbisier,P., Hess N., Berben G., Lubeck P.S., de Loose M., Moran G., Henry C., Brera C., Folch I., Ovesna J. and van den Eede G. 2006. Kernel lot distribution assessment (KeLDA): a study on the distribution of GMO in large soybean shipments. Eur. Food Res. Technol., 224: 129-139.

Pascher K., Moser D., Dullinger S., Sachslehner L., Gros P., Sauberer N., Traxler A., Grabherr G. and Frank, T. 2011. Setup, efforts and practical experiences of a monitoring program for genetically modified plants - an Austrian case study for oilseed rape and maize. Environmental Sciences Europe, 23: 1-21.

Pauwels K., Breyer D., De Schrijver A., Goossens M. and Herman P. 2010. Contributions from scientific research to the risk assessment of GMOs. Lessons learned from a symposium held in Brussels, Belgium, 21-22 October 2010. Environmental Biosafety Research, 9: 113-121.

Pieniak Z., Verbeke W., Vanhonacker F., Guerrero L. and Hersleth M. 2009. Association between traditional food consumption and motives for food choice in six European countries. Appetite, 53: 101-108.

Prakash A. and Kollman K.L. 2003. Biopolitics in the EU and the U.S.: a race to the bottom or convergence to the top? Int. Stud. Quart., 47: 617-641.

Prat F. 2011. OGM: la bataille de l'information. Editions Charles Léopold Mayer, Paris, France. pp. 312.

Public Health Agency of Canada. 2002. Conference proceedings ot the international conference on post-market surveillance of genetically modified foods. Paper presented at: International conference on Past-market surveillance of genetically modified foods (Ottawa, Canada, Centre for surveillance Coordination. Canada). Available at: http:// www.phac-aspc.gc.ca/publicat/gmfcp-agmrc/index-eng. php [accessed 1 May 2012].

Reynolds M. 2004. How does Monsanto do it? An ethnographic case study of an advertising campaign. Interdisciplinary Journal for the Study of Discourse, 24: 329-352.

Richard A. 2011. Comment les Français regardent la science. La Recherche, 455: 84-88.

Roberts D., Unnevehr L., Caswell J., Sheldon I., Wilson J., Otsuki T. and Orden D. 2001. The role of product attributes in the agricultural negotiations. IATRC Commissioned Paper. Pp. xi+76. Available at: http://ageconsearch.umn.edu/ bitstream/14620/1/cp17.pdf [accessed 1 May 2012].

Rollin F., Kennedy J. and Wills J. 2011. Consumers and new food technologies. Trends Food Sci. Tech., 22: 99-111.

Rousu M., Huffman W.E., Shogren J.F. and Tegene A. 2004. Are United States consumers tolerant of genetically 
modified foods? Applied Economic Perspectives and Policy, 26: 19-31.

Sanvido O., Romeis J. and Bigler F. 2007. Ecological impacts of genetically modified crops: ten years of field research and commercial cultivation. Adv. Biochem. Eng. Biot., 107: 235-278.

Sanvido O., Widmer F., Winzeler M. and Bigler F. 2005. A conceptual framework for the design of environmental post-market monitoring of genetically modified plants. Environmental Biosafety Research, 4: 13-27.

Schermer M. 2001. GMO-free Alps: an alternative path in technology development? Mt Res. Dev., 21: 140-147.

Schneider M.C. 2007. Capital'-Interview mit dem NestléCEO Peter Brabeck-Letmathe: An Genprodukten ist noch keiner gestorben, an Bioprodukten schon' Interner Nachfolger für den Nestlé-Chefsessel Entscheidung im September. In: Capital. Available at: http://www.presseportal.de/ pm/8185/1025069/capital_g_j_wirtschaftspresse [accessed 1 May 2012].

Schouten H.J., Krens F.A., Jacobsen K. and Jacobsen E. 2006. Cisgenic plants are similar to traditionally bred plants International regulations for genetically modified organisms should be altered to exempt cisgenesis. EMBO Rep., 7: 750-753.

Sheldon R., Cleghorn N., Penfold C., Brown A. and Newmark T. 2009. Exploring attitudes to GM food. Final Report, Food Standards Agency, Social Science Research Unit, UK (ed.). pp. 88. Available at: http://www.food.gov.uk/news/ newsarchive/2009/nov/gmreport [accessed 1 May 2012].

Shike J. 2011. Severe root damage to Bt corn confirmed in Illinois. Checkbiotech. Available at: http://greenbio. checkbiotech.org/news/severe_root_damage_bt_corn_ confirmed_illinois [accessed 1 May 2012].

Stapleton P. 2011. Contested technology, contested governance: the fight over GMO regulation in France. Paper presented at the 2011 Annual Meeting of the American Political Science Association. Seattle, WA, USA. Available at: http:// ssrn.com/paper=1913996 [accessed 1 May 2012].

Strauss D.M. and Strauss M.C. 2009. Globalization and national sovereignty: controlling the international food supply in the age of biotechnology. Journal of Legal Studies in Business, 15: 75-94.

Taylor I.E.P. (ed.). 2007. Genetically Engineered crops. Interim Policies, Uncertain Legislation. Haworth Press Inc., Philadeplphia.

The Melman Group. 2006. Report to the Pew Initiative on Food and Biotechnology. Review of public opinion research. The Melman Group (ed.). pp. 11. Available at: http://www. pewtrusts.org/uploadedFiles/wwwpewtrustsorg/Public Opinion/Food_and_Biotechnology/2006summary.pdf [accessed 1 May 2012].

TNS Opinion \& Social. 2010. Eurobaromètre 72. L'opinion publique dans l'Union Européenne. Brussels, Belgium. Available at: http://ec.europa.eu/public_opinion/archives/ eb/eb72/eb72_en.htm [accessed 1 May 2012].

van Dijk H., Fischer A.R.H. and Frewer L.J. 2011. Consumer responses to integrated risk-benefit information associated with the consumption of food. Risk Anal., 31: 429-439.

Vermij P. 2006. Liberty Link rice raises specter of tightened regulations. Nature Biotechnol., 24: 1301-1302.

Wilhelm R., Sanvido O., Castanera P., Schmidt K. and Schiemann J. 2009. Monitoring the commercial cultivation of Bt maize in Europe - conclusions and recommendations for future monitoring practice. Environmental Biosafety Research, 8: 219-225.

Winickoff D., Jasanoff S., Busch L., Grove-White R. and Wynne B. 2005. Adjudicating the GM food wars: science, risk, and democracy in world trade law. The Yale Journal of International Law, 81-123.

Zel J., Cankar K., Ravnikar M., Camloh M. and Gruden K. 2006. Accreditation of GMO detection laboratories: improving the reliability of GMO detection. Accredit. Qual. Assur., 10: 531-536.

Zel J., Mazzara M., Savini C., Cordeil S., Camloh M., Stebih D., Cankar K., Gruden K., Morisset D. and van den Eede G. 2008. Method validation and quality management in the flexible scope of accreditation: an example of laboratories testing for genetically modified organisms. Food Anal. Method., 1: 61-72. 